\title{
The Concept of Developing Local Wisdom-based Tourism Villages in Cirebon Regency, West Java, Indonesia: Integrated Marketing Communication Perspective
}

\author{
${ }^{1}$ Nurul Chamidah, ${ }^{2}$ Khaerudin Imawan, ${ }^{3}$ Mudhofar \\ ${ }^{1}$ Extension and Development Communication Program \\ Universitas Gadjah Mada \\ Yogyakarta, Indonesia \\ ${ }^{2}$ Communication Department \\ Universitas Swadaya Gunung Jati Cirebon \\ Departement of Architecture \\ ${ }^{3}$ Sekolah Tinggi Teknologi Cirebon, \\ Jawa Barat Indonesia \\ nurul.chamidah@ugm.ac.id
}

\begin{abstract}
The tourism in Indonesia has become a complex sector, and therefore, it needs a communication pattern to improve tourism attraction and all tourism stakeholders. At this time, the marketing communication concept has not only been applied to products and services but also begun to be developed and applied in various fields, and one of them is the tourism. One of the tourism communication forms or products is the establishment of a tourism village concept. Specifically, the concept of tourism village is an effort to develop and create the village community's prosperity. This concept will gradually become a regional tourism flagship. This research is aimed at analyzing the activity of Integrated Marketing Communication, which is a specific integration of five marketing communication activities commonly used in the tourism villages to communicate their tourism attraction potentials to the consumers. This research uses the qualitative description technique to collect data in the form of a deep interview with the village administration and the chairperson of tourism business activity groups. The result of the research shows that IMC performed by tourism village administration has begun to be applied to planning, performing and evaluation. However, IMC has been done completely, but it is not maximal in the planning of IMC that does not focus and has no special integrated marketing communication evaluations. The IMC concept starts from planning, implementing, and evaluating. At the planning step, Cirebon tourism village needs targeting, positioning, aiming and budgeting. At the implementation step, the tourism village decides the communication program assimilation, chooses media, makes messages, and determines moments.
\end{abstract}

Keywords: Integrated marketing system, local wisdom, tourism village.

\section{INTRODUCTION}

At this time, the tourism is a belle of our national development. This sector will become the biggest footstool of national foreign exchange contributor after oil and gas. Tourism is a service industry handling and offering interesting things like cultures, nature beauty, arts, new experience, and other services of transportation, housing, food and beverages, and other related services. The tourism world as a complex product needs communication to communicate those interests to all tourists and tourism stakeholders. At the moment, the concept of marketing communication is not only applied to products and services but also in other fields where one of them is tourism to communicate those interests (Damanik:2013).

One of the ways to communicate tourism to make it developed is an appropriate marketing process. The marketing strategy is the entire step and condition needed to be well prepared before the services are given to the consumers to achieve the company's goals mainly in the marketing field (Tjiptono, 2000:6). In the modern era, the marketing strategy of the company needs the development beyond the qualified and competitive products and services. It needs an effective communication process to maintain harmonious relationships with the consumers. A good product will not make consumers aware of that product if the marketing communication is not effective nor efficient and this low awareness of consumers will make the supplies offered by the companies ineffective (Jatmiko, 2014:3). However, the marketing communication is then needed as a tool to implement the effective marketing strategy.

Don Schultz, one of the IMC models, explains that IMC is a process of managing all information sources of products or services intended to the consumers or prospective consumers affected by the consumer behavior aimed at increasing the sales and maintaining the loyalty of consumers (Anugrah, 2014:4). In 
contrast, Kotler (2008:120) explains that the activity of IMC is a specific integration of five communication activities mostly used by companies, which are advertising, personal selling, sales promotion, public relations, and direct marketing.

In the past two decades, the map of international tourism market tends to shift into a segment of the special tourism market. The characteristics of this special tourism lie in the motivation of tourists to visit special tourism spots and interact with various activities on the spot they are visiting. This motivation includes the intentions of tourists to enrich their knowledge, develop their self-capacity and adventures, and learn the local cultures.

One of the tourism sectors that grow so fast is the community-Based Tourism. The development concept of tourism emphasizes the involvement and roles of community in the development and implementation of tourism. This is aimed at making planning, managing, and sharing profits enjoyed by the community. One of the community-based tourisms is the tourism village. According to Asyari (2012), "a tourism village is an independent village, and with its potentials, it can sell its tourism attractions without involving investors." A tourism village offers the beauty of nature with its traditional culture managed by the community itself as the attracting factor. The development of tourism village gives the community that opportunity. The benefits can be finance, knowledge, etc. this happens since the tourism village gives its community an opportunity to directly contribute to the economic activities and ideas. A village that has become a tourism village will improve the interactions of the community and new people leading to the knowledge exchange.

A tourism village needs a huge of supports in the form of facilities and infrastructures that have a sense of art. The architectural review is needed to give a cultural touch so that the tourism village will be more aesthetics. According to Hutama (Isnaini: 2017), the architectural communication review is an art, method, or skill to convey and receive architectural information so that the communication targets could understand that message. The architectural technique emphasizes on the understanding of communication objects, which are room and architecture, goals and roles of good communication as the cultural functions.

One of the regions that have many potentials of cultural and historical heritages is Cirebon in the Province of West Java. This area has a strategic access located on the national roads connecting big cities like Bandung and Jakarta to other regions in Central and East Java. Also, the opening of Cikampek-Palimanan (Cipali) toll roads and the development of an international airport of Bandara Internasional Jawa Barat (International Airport of West Java BIJB) have become an opportunity to empower the village-based community. Some villages having local wisdom and supported by Small and Medium-sized Entrepreneurship are Tegal Wangi and Sitiwinangun Villages. Those two villages are independently supported by village governments having a concept of tourism villages. The local government of Cirebon does not have an idea or a 5 -year action plan of tourism villages (Chamidah, 2016). However, the efforts made by village governments and community models have become a development concept of tourism villages as part of the community empowerment.

Figure 1. The location of Cirebon in Java Island Jawa

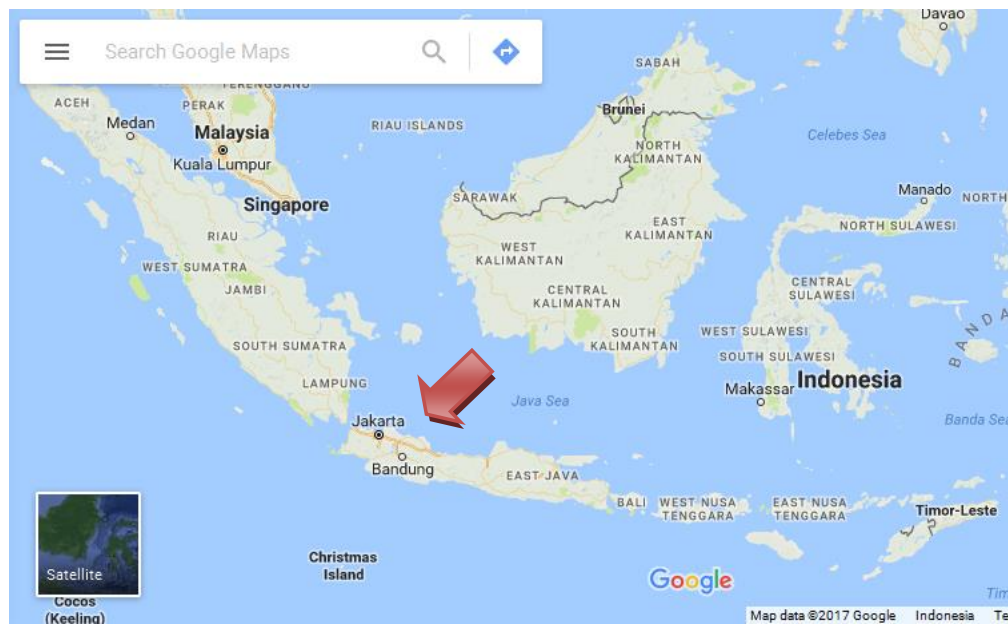

Source: Google Map

Figure 2. The strategic location of tourism villages in Cirebon referring to Cipali Toll roads, the main national road, and international airport

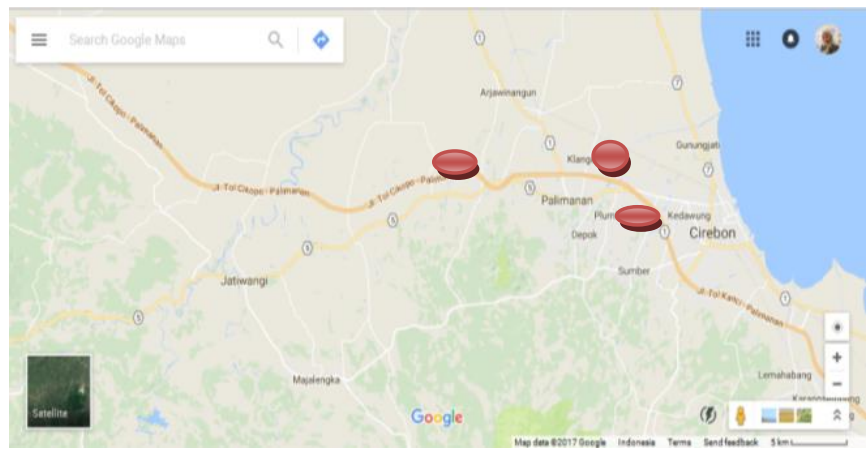

A tourism village or specifically a village expecting to be a tourism village does not have a 
big map or action plan as a tourism village. In this stage, the community only has an idea and sporadic efforts to make a tourism village without knowing the concept or staged to make it a tourism village. The bottom-up development concept where the initiatives and movements of the community as the related parties is the main factor leading to the successful of its plan.

Seeing the opportunities and threats as the tourism villages in Cirebon, the integrated marketing communication is needed including the planning, developing, and evaluating stages. Furthermore, this research applies the concept of architectural touch on the local wisdom-based facilities to support the development of tourism villages.

\section{METHODOLOGY}

The approach conducted in this research in the rationalistic approach. Data are collected through observations, interviews, and literature study. The research objects are three villages in Cirebon Regency, West Java, which are Sitiwinangun Village of Jamblang District, Tegal Wangi Village of Plered District, and Ciwaringin Village of Ciwaringin District. The interviews are conducted to the head of tourism awareness groups as well as the head of villages. Also, the observations are intensively conducted in all aspects of facilities and infrastructures of tourism villages supported by existing documents. The analytical technique that will be used to reach the facilities and infrastructures is using the analytical method of qualitative descriptive.

\section{RESULT AND DISCUSSION}

A.The potential analysis of local wisdom-based tourism villages in Cirebon

Tourism villages mainly the areas having local wisdom will attract more tourists. This refers to tourists who emphasize the educational tourism that can improve their knowledge when visiting the tourism villages. Cirebon Regency has at least three tourism villages with their competitive products. Those three villages are Sitiwinangun Village of Jamblang District with its competitive products of earthenware, Ciwaringin Village of Ciwaringin District with its competitive products of written batik, and Tegal Wangi Village of Plered District with its competitive products of rattan-based crafts.

Those three villages have one of the characteristics of community-based tourism where the idea comes from the community. The community-based tourism emphasizes the tourism development of "from the community, by the community, and for the community." This concept makes the local community aware of their potentials so that they have a sense of belonging to various natural resources and cultures as the assets of tourism development (Demartoto. 2009: 20-21).

The threats that the community faces are that they do not know how to manage and market their tourism villages. This refers to an unavailability of human resources having relevant knowledge and skills to manage the tourism villages. Therefore, this research tries to develop those local wisdom-based tourism villages using the integrated marketing communication process. It is expected that the management of tourism villages can market their villages according to the appropriate product knowledge and crafts to users and therefore, this will lead to the prosperity of their people.

Table1. The development analysis of Tourism Villages in Cirebon

\begin{tabular}{|c|c|c|c|c|}
\hline $\begin{array}{l}\mathrm{N} \\
\mathrm{o}\end{array}$ & Aspect & $\begin{array}{l}\text { Sitiwina } \\
\text { ngun }\end{array}$ & $\begin{array}{l}\text { Galmant } \\
\text { ro }\end{array}$ & $\begin{array}{l}\text { Ciwarin } \\
\text { gin }\end{array}$ \\
\hline 1. & $\begin{array}{l}\text { Forms of } \\
\text { local } \\
\text { wisdom } \\
\text { and } \\
\text { attractio } \\
\text { ns }\end{array}$ & $\begin{array}{l}\text { Earthen } \\
\text { ware } \\
\text { crafts, } \\
\text { history } \\
\text { and } \\
\text { religious }\end{array}$ & $\begin{array}{l}\text { Rattan } \\
\text { crafts }\end{array}$ & $\begin{array}{l}\text { Written } \\
\text { batik } \\
\text { crafts } \\
\text { using } \\
\text { natural } \\
\text { colorant } \\
\mathrm{s}\end{array}$ \\
\hline 2. & $\begin{array}{l}\text { Supports } \\
\text { from } \\
\text { Village } \\
\text { Governm } \\
\text { ents }\end{array}$ & $\begin{array}{l}\text { Fully } \\
\text { supporte } \\
\text { d }\end{array}$ & $\begin{array}{l}\text { Fully } \\
\text { supporte } \\
\text { d }\end{array}$ & $\begin{array}{l}\text { Not } \\
\text { maximu } \\
\text { m }\end{array}$ \\
\hline 3. & $\begin{array}{l}\text { Supporti } \\
\text { ng } \\
\text { Facilities }\end{array}$ & $\begin{array}{l}\text { Showroo } \\
\mathrm{m} \\
\text { Training } \\
\text { Centre }\end{array}$ & $\begin{array}{l}\text { Archway } \\
\text { s in } \\
\text { villages } \\
\text { Showroo } \\
\text { ms }\end{array}$ & $\begin{array}{l}\text { Archwa } \\
\text { ys in } \\
\text { villages } \\
\text { Showro } \\
\text { oms }\end{array}$ \\
\hline 4. & $\begin{array}{l}\text { Develop } \\
\text { ment } \\
\text { plan of } \\
\text { tourism } \\
\text { villages }\end{array}$ & $\begin{array}{l}\text { Not } \\
\text { available }\end{array}$ & $\begin{array}{l}\text { Not } \\
\text { available }\end{array}$ & $\begin{array}{l}\text { Not } \\
\text { availabl } \\
\text { e }\end{array}$ \\
\hline 5. & $\begin{array}{l}\text { Roles of } \\
\text { Private }\end{array}$ & $\begin{array}{l}\text { Supports } \\
\text { from } \\
\text { Business } \\
\text { Forum of } \\
\text { Cirebon }\end{array}$ & $\begin{array}{l}\text { Supports } \\
\text { from the } \\
\text { Associati } \\
\text { on of } \\
\text { Rattan } \\
\text { Business } \\
\text { men }\end{array}$ & $\begin{array}{l}\text { Support } \\
\text { s from } \\
\text { CSR of } \\
\text { Indoce } \\
\text { ment } \\
\text { Cirebon }\end{array}$ \\
\hline 6. & $\begin{array}{l}\text { Marketin } \\
\text { g of } \\
\text { Villages' }\end{array}$ & $\begin{array}{l}\text { Village } \\
\text { Website } \\
\text { and }\end{array}$ & $\begin{array}{l}\text { Village } \\
\text { Website } \\
\text { and }\end{array}$ & $\begin{array}{l}\text { Village } \\
\text { Website } \\
\text { and }\end{array}$ \\
\hline
\end{tabular}




\begin{tabular}{|l|l|l|l|l|}
\hline & $\begin{array}{l}\text { potential } \\
\text { s }\end{array}$ & $\begin{array}{l}\text { joining } \\
\text { the } \\
\text { exhibitio } \\
\text { ns }\end{array}$ & $\begin{array}{l}\text { joining } \\
\text { the } \\
\text { exhibitio } \\
\text { ns }\end{array}$ & $\begin{array}{l}\text { joining } \\
\text { the } \\
\text { exhibiti } \\
\text { ons }\end{array}$ \\
\hline 7. & $\begin{array}{l}\text { Human } \\
\text { resource } \\
\text { s/ } \\
\text { knowled } \\
\text { ge and } \\
\text { skills }\end{array}$ & $\begin{array}{l}\text { Having } \\
\text { the } \\
\text { manage } \\
\text { ment of } \\
\text { tourism } \\
\text { awarene } \\
\text { ss group }\end{array}$ & $\begin{array}{l}\text { Not } \\
\text { available }\end{array}$ & $\begin{array}{l}\text { Not } \\
\text { availabl } \\
\text { e }\end{array}$ \\
\hline
\end{tabular}

Source: The analysis result and field observation in 2007

The table above shows that there are opportunities and challenges for the development of tourism villages in Cirebon. The community awareness can make the tourism sector a way to empower themselves through their ideas. This shows the process characteristics of bottom-up development. Therefore, the idea and implementation of tourism villages will be part of the community, and they will maintain those villages since they have development values. In making tourism villages, a huge amount of costs is needed to fulfill the facilities and infrastructures of their areas. However, after two years since their launches, the tourism villages develop so significantly. The Village Government and local models have taken their active roles marked the collaboration with stakeholders to develop their villages.

The challenges that the villages have are that they do not have the development plans of tourism villages. Their work patterns are not well organized but more spontaneous. This makes the development of tourism villages runs slowly, and the development is not well organized. Therefore, the appropriate guidance of stakeholders like the community, governments, private parties, and scholars is necessary. As a result, the work steps to make the tourism villages can happen.

The concept of tourism village development is divided into two parts, which are spatial and non-spatial concepts.

The spatial concept can be:

1. Landmark or tetengger as the special characteristics can sell or as an identity including the products of local genius. The oriented architectural concept will help create local wisdom based on the architectural form and rooms. For example, a huge earthenware jug marks Sitiwinangun Village, rattan handicrafts and huge rattan chair are the identity of Tegal Wangi Village, and batik making statue is the symbol of Ciwaringin Village. Also, the design of tetengger can be used as the welcome archways, showroom, and restaurants. These landmarks can be the locations of self-taken photographs of visitors.

2. Facilities and infrastructures of village regions as the activities that can fulfill the visitors' activities can be well accomplished. One of the workshops, which are close to the similar handcrafters, is prepared for visitors. Therefore, a special room is needed to enable a direct learning process. The design of training center marks the characteristics of those regions like the use of existing handicraft ornaments.

3. Zoning of each function will then support each other. It will also identify different functions.

4. The circulation related to the groove towards the function of tourism village and reaching the locations from the city center will determine the way to the tourism spots including the parking areas and pedestrian ways.

5. The locations of restaurants selling traditional food, comfortable showrooms, clean rest rooms, and rest areas for visitors are important.

The non-spatial concepts are:

1. Strengthening the regulations or government's policies regulating the development process

2. Making the group of tourism awareness that has skills and knowledge to manage the tourism villages

3. Giving an understanding to the community concerning the tourism village programs

4. Needing the participations of the community in all decisions and work programs

5. Keeping the local wisdom possessed by the villages

The development concept of tourism villages in the Integrated Marketing Communication (IMC)

The marketing concept of local wisdombased tourism villages in Cirebon needs several stages, which are planning, implementing, and evaluating.

\section{B.Planning Stage}

The tourism villages plan some activities that will be implemented in the next 1 year and adjust them to the existing budget. After planning, the next step is to determine the marketing 
communication strategy that is effective to achieve that goal.

\section{C.Implementation Stage}

1. Identifying the audience of tourism villages that include segmentation of students, hotel visitors, and companies' employees

2. Selecting messages, finding creative team members to design brochure, leaflets, and booklets

3. Selecting media, printing media, electronic media, and online media in making the marketing communication strategy to increase the visits of tourists in the tourism villages

4. Using social media like Facebook, twitter, and Instagram to be accessed by netizens so that they can get information that attracts them to know more about the products of tourism villages

5. Designing the production costs and the budget of marketing communication is always essential for the marketers before making a decision. If the cost is too low, the sales volume will not be achieved. Otherwise, if the cost is too high, the marketing process will not be efficient and reduce the profits

6. Collecting feedback:
a. Doing a market analysis activity, knowing the satisfaction level of tourists by giving them questionnaires
b. Having interactive dialogues on radio and television
c. Meeting with related tourism parties or institutions

\section{D.Evaluation Stage}

An evaluation is conducted in December to make sure cultural and tourism work successfully. In the evaluation, all members express their conducted promotion activities. A minute of meeting and publication, as well as the meeting outcome, are essential as the suggestion for future improvement.

The marketing communication is a production process and information or message conveying through one or more channels to the target public. It is conducted sustainably and in two ways aimed at supporting the marketing effectivity of a product. The marketing communication can help make the prospective customers and sellers meet in a more effective exchange relationship and enable all parties to achieve a satisfactory exchange relationship. However, local government has not managed the marketing communication strategy of tourism villages in Cirebon. Therefore, only each village government conducts all activities of marketing communication of tourism villages.

Kotler (2008:120) explains that an IMC activity is a specific combination of five activities of marketing communication mostly used by companies, which are advertising, personal Selling, sales promotion, public relations, and direct marketing. This concept will be developed to promote the tourism villages.

\section{Advertising}

The first mixed marketing communication was advertising. Advertising is a marketing communication activity using mass media to achieve the process of message conveying.

Advertising works as the communication tool to the public. Good advertising must be able to invite or influence the emotion of readers. The information put on the advertisements must consist of interesting information.

The existence of earthenware products originating from Sitiwinangun Village, written batik of Ciwaringin Village, and rattan-based handicrafts of Galmantro Village should be promoted as the handicraft products inherited the high value of local wisdom. In contrast, those three villages will not be recognized as the tourism villages if they only give labels to those villages without promoting them. A process of communication in the form of advertising is essential. The communication through advertising informs the products aimed at persuading the community of either local or international tourists and makes them interested in the local products. The communication messages are designed and made as interesting as possible according to their segments, targets, and identities of products, which are later published through media according to their targets and strategies.

\section{Personal Selling}

Personal selling is an oral promotion tool offered to one or more prospective customers aimed at making the purchase transactions happen and it benefits both parties by using human as the promotion tool.

The main purpose of personal selling is to make direct marketing communication with stakeholders or consumers as the parties having potentials to buy the community's handicrafts and visit the villages for tourism. Personal Selling 
is conducted actively by the management, local people, handcrafters, local officials or other parties having authorities to conduct personal selling. They must actively make market offers and follow up prospective customers so that they agree to buy local handicraft products and enjoy various tourism spots of a village.

\section{Sales Promotion}

Sales promotion is a direct guidance where the value shift of a product on the sales power happens. Sales promotion can be conducted by giving some purchase coupons, samples, and other related activities.

The other activities include making some marketing communication through special offers as part of the promotion that is part of the identity of handicraft products sold at a very affordable price of qualified products or offering the tourism services at a promotional price. The sales promotion can utilize social media to promote the most inventive of products of the community and offer packages to visit the tourism villages. This kind of packages should be directly promoted on social media to make it viral.

\section{Public Relation}

Publications are related to the images of a company. In delivering information through publications, consumers will recognize the facts of the product existences and the information is considered having an objective truth. Publications can raise awareness and encourage consumers to try a product or service (Kennedy, 2006:21-22).

Making good relations with all parties inside the villages or outside ones like the community groups, art, and cultural activists, and village models have a good impact on the public. Also, making some communication though media by using a direct communication approach is essential. After holding some events like ceremonies and traditional and art programs held in a tourism village, it is necessary to have press conferences.

\section{Direct Marketing}

Direct marketing is an activity held in specific places aimed at seeing the consumers by making some activities liked and needed by them. Through this kind of activity, the products can inform their existence to the customers. For example, making national or international-based events will attract visitors. The activities include the music performances in a building or field or other competitions. The time and process to perform all of these depend on the needs and conditions of the products.

Table 2

Analysis of integrated marketing communication for the tourism villages in Cirebon Regency

\begin{tabular}{|c|c|c|}
\hline No & IMC Aspects & Analysis \\
\hline 1. & Advertising & $\begin{array}{l}\text { - Arranging the } \\
\text { advertising materials of } \\
\text { tourism villages put on } \\
\text { mass media } \\
\text { - Making integrated } \\
\text { advertising of tourism } \\
\text { villages by having } \\
\text { village-based websites } \\
\text { in the } \\
\text { - Putting } \\
\text { advertisements on local } \\
\text { media like local } \\
\text { newspapers and TV } \\
\text { stations } \\
\text { - Involving the national- } \\
\text { based media to promote } \\
\text { the cultural tourisms } \\
\text { Optimizing the use of } \\
\text { social media like } \\
\text { facebook, Instagram, } \\
\text { and twitter }\end{array}$ \\
\hline 2. & $\begin{array}{l}\text { Personal } \\
\text { Selling }\end{array}$ & $\begin{array}{l}\text { Joining some } \\
\text { exhibitions } \\
\text { - Opening outlets in the } \\
\text { crowd centers, i.e., car } \\
\text { free day }\end{array}$ \\
\hline 3. & $\begin{array}{l}\text { Sales } \\
\text { Promotion }\end{array}$ & $\begin{array}{l}\text { - Making the tourism } \\
\text { packages in } \\
\text { collaboration with the } \\
\text { travel agents } \\
\text { - Making some offers to } \\
\text { partners of travel } \\
\text { agents } \\
\text { - Giving direct offers to } \\
\text { have partnerships with } \\
\text { the Education Agency or } \\
\text { educational institutions } \\
\text { to make tourism village } \\
\text { visits part of their } \\
\text { tourism visits }\end{array}$ \\
\hline 4. & $\begin{array}{l}\text { Public } \\
\text { Relation }\end{array}$ & $\begin{array}{l}\text { - Working together with } \\
\text { related tourism villages } \\
\text { - Working together with } \\
\text { hotels and malls } \\
\end{array}$ \\
\hline 5. & $\begin{array}{l}\text { Direct } \\
\text { Marketing }\end{array}$ & $\begin{array}{llll}\text { - Making some festival } \\
\text { events }\end{array}$ \\
\hline
\end{tabular}




\section{CONCLUSION}

The research outcome shows that a local wisdom-based tourism village has the followings:

1. A tourism village needs to analysis the potentials and challenges they have by using the SWOT analysis. Three potential villages as local wisdom-based tourism villages in Cirebon are the process of bottom-up development, and they need the guidance of stakeholders to be developed tourism villages. The main things that need to be taken into account are the empowerment of human resources to manage the tourism villages and policy making to develop them.

2. In the integrated communication marketing, to market a local wisdom-based tourism village, it needs three stages that are planning, implementing, and evaluating. Specifically, the concept of tourism village development can be made through advertisings, personal selling, sales promotion, public relation, and direct marketing.

3. The development of tourism villages should be supported by infrastructures that have special characteristics and perform the special cultures of those villages as part of the development. These will be the characteristics of that cultural work.

\section{ACKNOWLEDGMENTS}

Acknowledgements are delivered to all lecturers joining the research institute of Open Mind Institute who always train their critical thinking in making some work.

\section{REFERENCES}

Anugrah, Clarissa. 2014. The Role of Marketing Public Relations Incognitive Decision Making Process Though the Brand Awareness. Jurnal interact, 3 (1), 1-14.

Chamidah, Nurul, Titis Resti dkk (2016) Komunikasi Pariwisata dalam Menggagas Tiga Desa Wisata Usaha Mikro Kecil dan Menengah di Cirebon. Prosiding Penyuluhan dan Komunikasi Pembangunan, Strategi Pemberdayaan Masyarakat di Era masyrakat ekonomi ASEAN. Universitas Gadjah Mada, Yogyakarta

Damanik,Janianton. 2013. Pariwisata Indonesia Antara Peluang dan Tantangan. Yogakarta: puspa UGM dan Andi.
Demartoto, Argyo. 2009. Pembangunan Pariwisata Berbasis Masyarakat. Surakarta: Sebelas Maret University Press

Isnaeni, Santi. 2017. Konflik dan Negoisasi di Dalam Perspektif: Arsitektur, Teknologi dan Komunikasi. Prosiding Internasional Komunikasi, Religi dan Budaya. APIK-PTM. Ponorogo 303-321

Jatmiko. 2014. Komunikasi Pemasaran Sebagai Strategi Memperluas Pasar: April, 29. Diperoleh dari www.esaunggul.ac.id/artcel/komunikasi pemasaran sebagai strategi memperluas pasar.

Kotler, Philips. 2008. Prinsip-Prinsip Pemasaran Edisi Keduabelas. Jakarta Erlangga.

Kennedy. Jhon EE \& R. Dermawan Soemagara (2006). Marketing Communication. Jakarta: PT Bhuana Ilmu Populer

Purwanto, Iwan.2008. Manajemen Strategi. Bandung. Yrama Widya. 